\title{
The Origin of the Caland System and the Typology of Adjectives
}

\author{
Chiara Bozzone* \\ University of California, Los Angeles \\ chiarabozzone@gmail.com
}

\begin{abstract}
This paper argues that the Caland system rests on a Pre-PIE verb-like adjective class, which formed root aorists. The Caland system as we know it came to be when PIE shifted to having a noun-like adjective class, and the Caland roots had to be adapted to the new system via derivation (while the old root aorists were gradually lost). Evidence for root aorists to Caland roots in Vedic is reviewed, and a typologically informed scenario for the shift is proposed. Finally, the paper argues that this scenario clarifies the origin of the *-eh ${ }^{-}$stative in Indo-European (following Jasanoff (2002-2003)'s account), which would have arisen as PIE shifted from verb-like adjectives to nominal adjectives, and came to have a switch adjective system based on aspect.
\end{abstract}

\section{Keywords}

adjectives - typology - stative - Caland - participle - instrumental - Vedic - property concepts

\footnotetext{
* I would like to thank the participants of the Kyōto-UCLA workshop on Indo-European, the participants of the East Coast Indo-European Conference XxxıII, as well as Brent Vine and Stephanie Jamison, for their feedback on various versions of this paper. In particular, I am grateful to Toru Minamimoto for his help with the Japanese material, and to Ryan Sandell. Every infelicity is, of course, entirely my responsibility.
} 
In recent years, a great deal of attention has been devoted to the study of the Caland system (Caland 1892, 1893), a morphological complex attested across the Indo-European family that derives a number of nominal and verbal stems from roots with adjectival meanings (Nussbaum 1976). ${ }^{1}$ A recent treatment of the topic is Rau 2009, which includes a rich morphological description and lexical survey of the system. An example of a Caland root is PIE ${ }^{*} h_{1} r e w d^{h}$ - 'red'; this root forms:

- Verbs:

- Statives (meaning 'be red'), as in Latin rubēre, Old Irish -ruidi, Old High

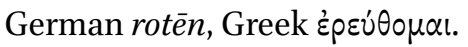

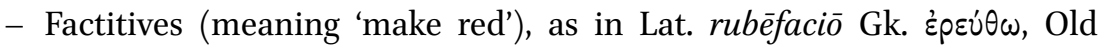
English rēodan.

- Fientives (meaning 'become red'), as in Lat. rubēscō.

- Nouns, as in Lat. rōbur 'oak tree', on roðra 'blood'.

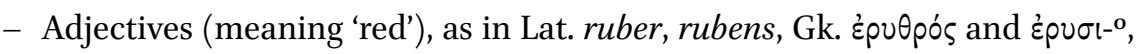
Skt. rudhirá-, etc.

This root displays typical Caland behavior in that: (1) all of these formations appear secondary in nature, but they cannot be synchronically derived from

1 In the terminology introduced by Dixon 1982, we can say 'property concept' meanings instead of 'adjectival' meanings. Examples of property concept meanings are listed under section 2 below. Of course, stating that a root/word has adjectival (property concept) meaning is not the same as stating that it belongs to an adjective class in any given language (as seen below, different members of the Caland system can be synchronically identified as nouns, verbs, and adjectives in the daughter languages). In every given language, assignment of a word to a word class is not predicated on its semantics, but on language-internal grammatical factors (such as a word's distribution, syntactic function, and the morphological and syntactic categories for which it can be marked). What is predicated on language-universal semantic criteria is the labeling of such word classes (as nouns, adjectives, verbs, etc.): for each language, once we have established on the basis of internal grammatical criteria that some lexical items form a word-class, we will label that word-class 'adjective class' (or 'noun class', or 'verb class') based on the semantics of the words included (Schachter and Shopen 2007:1-2). Thus, a word-class which mostly contains words denoting property concepts will be labeled 'adjective class'; one that contains words denoting objects or entities will be labeled 'noun class', etc. This paper is in large part devoted to establishing how some PIE roots with adjectival (property concept) meaning and a specific derivational profile (i.e., the Caland roots) were distributed across different word-classes at different times in the history of IE. 
an existing root formation in the daughter languages; this pattern gives the impression that the suffixes involved in these derivations are effectively "substituting" for each other; ${ }^{2}(2)$ the formations seem to imply one another, in the sense that having one formation (say, $\mathrm{a}^{*}$-ro- stem adjective) will make another (say, an ${ }^{*}-i$ - form in the first member of a compound, or an ${ }^{*}-e h_{1}$ - stative verb) more likely. ${ }^{3}$ Open questions are how and why this system came into being, and what function it had in the parent language. ${ }^{4}$ This paper discusses some typological considerations that bear on these issues; in particular, it argues that: (1) Caland roots were the oldest members of the IE adjective class; ${ }^{5}(2)$ Caland roots were originally verbal, not nominal, in nature, and formed root aorists (traces of which we can still clearly find in Vedic); (3) at some stage of PIE, Caland root aorists took part in a SWITCH ADJECTIVE SYSTEM, which can explain how ${ }^{*}-e h_{1}$ - statives were originally derived.

Roots taking part in the Caland system form the oldest, most conservative layer of adjectives in Indo-European. This claim can be established on morpholog-

2 Caland's law was in fact first described (Caland 1892, 1893) as a regular pattern of affix substitution, whereby, for instance, the PIE suffix *-ro- is replaced by ${ }^{*}-i$-in the first member

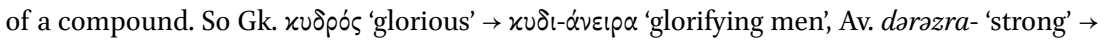
dərəzi-ra $\vartheta$ - 'having a strong chariot' (cf. Fortson 2010:137). The work of Nussbaum (1976) later established Caland's law as part of the larger complex now known as the Caland system. The unavailability of synchronic root formations next to derived formations is not an exclusive feature of the Caland system (root nouns and root verbs are after all relatively small classes even in the oldest IE languages), but it is an important part of how the system has been traditionally described.

3 For a history of the problem, and more extensive illustration, see Rau 2009:67-71.

4 Another important open question, which will not be addressed here, is how to precisely delimit the system in PIE and each of the daughter languages, especially in consideration of the fact that it can grow in productivity and acquire new members (as argued by Rau 2009). Some important sub-questions here are: what are the language-specific criteria for establishing membership in the system; how do membership criteria differ between PIE and each daughter language; under which circumstances should we reconstruct membership to PIE; what are the specific predictions that membership in the system does for each language.

5 As I will argue below, this adjective class was quite different from the adjective classes attested in the daughter languages. It had a verb-like morphosyntactic profile, similar to the class of $-i$ adjectives in Japanese (see section 3 below), and could thus be considered a sub-class of intransitive verbs, possibly part of the $h_{2} e$-conjugation (see section $5 \cdot 3$ below). 
ical and semantic grounds. Morphologically, roots taking part in the Caland system display the more conservative behavior in forming comparatives and superlatives: in IE languages (like Greek, Sanskrit, and Slavic) that have two sets of comparative and superlative morphemes, one unproductive (inherited IE comparative *-yos- and superlative *-is(-)te/o-), and one productive (innovative comparative Gk. $-\tau \varepsilon \rho-\varepsilon / 0$-, Sanskrit -tara- and superlative Gk. $-\tau \alpha \tau-\varepsilon / 0$, Sanskrit -tama-), Caland roots reliably take the older, unproductive set. ${ }^{6}$ Examples are easy to find:

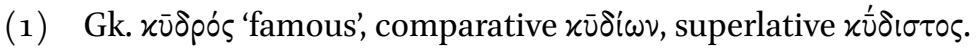

(2) Ved. bṛhánt 'lofty', superlative bárhișța-.

In effect, IE languages like Greek and Sanskrit can be said to have two distinct adjective classes (based on their morphological behavior and productivity), and Caland roots fall within the older of the two. ${ }^{7}$

This morphological observation can be confirmed by semantic considerations. The core roots taking part in the Caland system all belong to the most basic semantic types pertaining to adjectives crosslinguistically; these are (as described by Dixon 1982) the semantic types of DIMENSION, AGE, VALUE, and COLOR. Even languages with very small, closed adjective classes are likely to have a few adjectives belonging to these types. Many Caland roots also belong to the semantic types of PHYSICAL PROPERTY and HUMAN PROPENSITY, which are the next most basic types of adjective crosslinguistically. Within each of these semantic types, members of Caland system occupy cardinal positions into the daughter languages (Rau 2009:107). In other words, whatever the size and morphosyntactic profile of the PIE adjective class (which I will discuss below), Caland roots are likely to have formed its oldest and most central members.

6 For a recent investigation of the primary comparative and its ties to the Caland system, see Rau 2014.

7 Handbooks normally present the difference between the two sets of comparative and superlative morphemes as a matter of base selection: the first set attaches to roots, while the

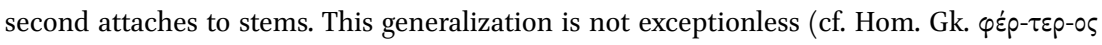
'better, stronger', $\varphi$ i $\lambda$ - $\tau \varepsilon \rho-\circ \varsigma / \varphi$ i $\lambda$ - $\tau \alpha \tau-o \varsigma$ 'dearer/dearest' etc., which are made to roots), and it masks the greater archaicity of the first set. In the terms of historical linguistics, it is the different productivity of the two processes that clearly sets them apart, and identifies the first set as most archaic. On productivity as a criterion of innovation and archaism in historical linguistics, see generally Sandell 2015 . 


\section{The Typology of Adjective Classes}

Languages vary greatly as to how they encode adjectival (i.e. property concept) meanings. Simplifying somewhat, some languages have adjective classes that behave more like nouns (like Italian and English), and some have adjective classes that behave more like verbs (like Bororo, of the Macro-Gê family). ${ }^{8}$ The examples below show how, in Bororo, predicative adjectives inflect as verbs do (Stassen 2013, after Crowell 1979:26, 50):

\section{(3) i-mago-re}

1sg.speak.NEUTRAL

'I speak/spoke'

(4) i-kure-re

1sg.tall.NEUTRAL

'I am/was tall'

The choice between verb-like adjectives and noun-like adjectives tends to be an areal feature (Stassen 2013). Languages can also change their strategy for encoding adjectival meanings over time, and this can result in one language having two separate classes of adjectives, each showing a distinct morphosyntactic profile. This is the case of Japanese (in the analysis of Dixon 2010:32-36), which has an older, closed class of adjectives with verb-like behavior ( $-i$ adjectives, also called inflected adjectives) and a newer, open class of adjectives ( $n a$ and no adjectives, also called uninflected adjectives) with noun-like behavior. In Japanese, verb-like adjectives inflect for tense directly, without a copula:

\section{(5) kono neko-wa kawai-i \\ this cat-TOP cute-NPST \\ 'this cat is cute'}

8 Adjectival classes come in many flavors, and their characterization is often trickier than that of verb or noun classes. To start with, one should assess whether a class of adjectives can be established at all for a given language, based on language-internal grammatical criteria. Dixon (2010:62) argues that all languages have an adjective class, even though some may be vanishingly small (and adjective classes can be open or closed). Next, one can decide whether the morphosyntactic profile of the adjective class is closer to that of nouns or verbs in that language (in many languages, adjective classes can share features with one or the other), or whether it does not resemble either. It is in this sense that we talk about verb-like adjective classes or noun-like adjective classes. Based on these considerations, adjectives can then be 
(6) ano neko-wa kawaiku-na-i

that cat-TOP cute-NEG-NPST

'that cat is not cute'

while nominal adjectives take the copula:

(7) kono neko-wa odayaka-da this cat-TOP calm-be.NPST 'this cat is calm'

(8) ano neko-wa odayaka-de-na-i that cat-TOP calm-be-NEG-NPST 'that cat is not calm'

just like nouns take the copula:

(9) neko-wa dōbutu-da cat-TOP animal-be.NPST 'the cat is an animal'

(10) neko-wa syokubutu-de-na-i cat-TOP plant-be-NEG-NPST 'the cat is not a plant'

Note that the verb-like adjectives in Japanese are not totally identical to verbs, and cannot take all of the verbal morphology that is otherwise available to verbs; they should rather be considered a subclass of intransitive verbs. ${ }^{9}$ Similarly, while Italian can be said to have noun-like adjectives (like nouns, they take the copula and inflect for gender and number), adjectives in Italian are not identical to nouns, and can still be identified as a separate class on the basis of their morphosyntactic behavior (e.g., unlike nouns, they receive gender and number marking through agreement)..$^{10}$

described as their own class, or as a sub-class of nouns or verbs. For an introduction to the issues concerning adjectival classes and their typology, see Dixon 2010:62-114, with references. For a crosslinguistic survey of intransitive predication (including adjectival predication), see Stassen 1997 .

9 For adjectives in Japanese, see Tsujimura 2014:131-132, 137-140; Shibatani 1990:215-217; Kaiser et al. 2013:151-182.

$10 \quad$ For adjectives in English, see Dixon 2010:90. 


\section{$4 \quad$ Caland Roots as an Old Class of Verb-Like Adjectives}

I suggest that a situation similar to the Japanese one could account for the existence of the Caland system in PIE as a separate class of adjectives having a distinct mophosyntactic profile. Under this hypothesis, the Caland roots would represent the oldest class of IE adjectives, which behaved syntactically like verbs and took verbal inflection. In this layer of the proto-language, to say 'the cat is/becomes red', one would say 'the cat reds'. This pattern appears archaic and largely unproductive in PIE (as accessible through comparative reconstruction), but was arguably productive in Pre-PIE (as accessible through internal reconstruction and typological comparison). The inflection and exact semantics of such forms will concern us in section 5 below; for now, we can simply assume that these were primary root formations. Such Caland root verbs would then constitute the bedrock of Caland formations, and provide the base on which the rest of the system was eventually derived.

Later, when IE developed a noun-like adjective class (the productive one that we observe in all attested IE languages), Caland formations were gradually reshaped to fit within the new system. In this process, IE derived both nominal and verbal formations to the Caland roots. We would then have:

- New verbal formations: ${ }^{*} h_{1} r u d^{h_{-}} e h_{1}-y e / o^{-},{ }^{*} h_{1} r e w d^{h}-e / o^{-}$, etc.

- New nominal formations: ${ }^{*} h_{1} r e w d^{h}-i-/-u-/-r o-$ etc.

In this process of restructuring, the basic Caland root verbs were gradually eliminated as obsolete. This created the classic Caland configuration of secondary derivatives (the $-i^{-},-u^{-},-$ro- nominal types and the secondary verbal types), seemingly lacking a synchronic base. The Caland system as we usually describe it, straddling the line between nominal and verbal inflection, would be the result of such a restructuring. ${ }^{11}$ Remnants of the original situation are still visible in the older IE languages, which (unlike the modern ones) can still express a number of adjectival meanings through verbs. ${ }^{12}$

11 Perhaps already in the parent language, and surely in the individual languages, this pattern of derivation could then become productive (as Rau 2009 has illustrated) and spread beyond its original core. Tracking how this secondary spread may have happened in the mother language or in the daughters goes beyond the scope of this contribution.

12 For instance, within the semantic type of COLOR, Latin has stative verbs like ruberre 'to be red', but Italian only has change of state verbs like arrossire and rosseggiare 'to become red/redden'. 
In the remainder of this paper, I will: (1) point out some direct evidence for Caland root verbs in Vedic, supporting the idea that Caland roots still had verb-like behavior in PIE; and (2) illustrate how this scenario can help us refine Jasanoff's account $(1978,2002-2003)$ of the origin of the PIE ${ }^{*}-e h_{1}$ - stative.

While the idea that (Pre-)PIE had verb-like adjectives may seem novel, and the switch between verb-like adjectives in Pre-PIE and noun-like adjectives in PIE requires motivation, two kinds of typological considerations make this scenario at least plausible. First, Pre-PIE may have been, in the terminology of Nichols 1986, a HEAD-MARKING LANGUAGE (see in this direction Kortlandt 1983,2008 ), and head-marking languages tend to have verb-like adjectives. Second, Pre-PIE was probably an ASPECT-MARKING LANGUAGE, and aspectmarking languages also tend to have verb-like adjectives (Stassen 1997:357, also quoted in Balles 2009:10). As PIE and its daughter languages moved away from both features, a change in adjective typology would be likely. In the appendix below, I shall explore these claims for Pre-PIE in greater detail. Of course, any account at such depth of reconstruction is necessarily speculative, and should be taken as such. Luckily, one does not have to entertain the deep scenarios discussed there to believe that the Caland roots were still verbal in nature in PIE: in the following section, we shall examine some direct evidence of Caland roots that formed root aorists in the Rgveda.

The first contribution that emphasized how Caland roots are connected to a number of verbal categories in IE was Watkins' 1971 paper on the $-\bar{e}$ - stative. Following in this line of inquiry, Rau (2009) has illustrated how verbal formations play a central part in the Caland system. In particular, Rau discussed a number of ways in which Caland roots form characterized presents in Greek and Indo-Iranian (2009:136-160). One striking fact that has not yet been reported, however, is that some of these Caland roots form root aorists in Vedic. Such root aorists would constitute first-hand evidence of the verbal behavior of Caland roots still in the earliest stages of Vedic.

\subsection{Caland Participles in Vedic}

Lowe (2011) has compiled a long list of isolated Caland participles in Vedic (both active and middle), which morphologically look like aorist participles, and are adjectival in meaning. In Table 1, I present Lowe's list sorted according to the semantic areas listed in section 2 above. ${ }^{13}$

13 Not all the forms listed here will withstand scrutiny, and I will focus my discussion below 
Semantic area

bṛhánt- 'high', rhánt- 'small, weak', mahānt- 'great', prathāná- 'broad' Dimension

rúśant- 'bright, brilliant', śucánt- 'bright, pure', citánt- 'brilliant',

Color

śvitāná- 'white'

járant-/juránt- 'old'

AgE

bhrájant- 'sparkling', prșánt- 'spotted', śubhāná- 'beautiful', piśāná-

PHYSICAL

'adorned'

Property

dhrșánt- 'bold', dódhant- 'violent', tujánt- 'eager', sáhant- 'victorious', HumAN uśánt- 'willing, desirous', trșāṇá- 'thirsty', prasahāná- 'victorious'

Propensity

While Lowe interprets such forms as nominal forms (which happen to look like participles, but are synchronically unrelated to participles), I would interpret at least some of them, under the theory I am proposing here, as the isolated and fossilized participles of old Caland root aorists. That we would find such stranded participles is not surprising, if we take adjective usage into consideration. We know that adjectives in general appear in two different syntactic contexts: attributive function and predicative function.

(11) Predicative: the cat is red

(12) Attributive: the red cat

In predicative function, we would expect Caland adjectives to use finite verbal forms (as we shall see in section 5.1 below). In attributive function, if the Caland adjectives are to behave like verbs, we would precisely expect participles: ${ }^{14}$

on a smaller subset. Lowe has since presented an extended treatment of the middle participles to Caland roots in Vedic in Lowe 2012. A treatment of the active participles is forthcoming.

14 For examples of attributive strategies in other languages with verb-like adjectives (which often involve relativization, whose effects are similar to the IE participle), see Schacter and Shopen 2007:16-18. 
(13) The "redd-ing" cat: act: * $h_{1} r u d^{h}$-ént-; mid: * $h_{1} r u d^{h}-m h_{1} n o ́-$

In sum, I believe that the -anna-middle participles and -ant-active participles to Caland roots in Vedic are remnants of Caland root aorists used in attributive function. As the most noun-like exponents of the verbal paradigm, Caland participles had the highest chance of being preserved even as finite forms were lost. This is in fact similar to what can be observed in Romance languages such as Italian, where stranded participles of Latin Caland verbs often survive as isolated adjectives after their base verb (usually a present stem) has disappeared from the language or acquired a different meaning.

(14) Lat. sapiō 'to be intelligent', sapiens 'wise'. $\rightarrow$ It. sapiente 'wise'

(15) Lat. lucēre 'to emit light', lucens 'luminous' $\rightarrow$ It. lucente 'luminous'

(16) Lat. latêre 'to be hidden', latens 'hidden' $\rightarrow$ It. latente 'hidden'

Even though Italian can still productively form active participles in -Vnte, none of the adjectives above are synchronically derivable from existing base verbs in Modern Italian.

\subsection{The Morphological Network of Caland Root Aorists in the Rgveda}

The Vedic evidence, however, is not limited to fossilized and isolated participles. In fact, while many of the participles above are effectively isolated, many others stand at the center of a vast morphological network, which I believe rests on old root aorists with intransitive meaning. As we shall see in section 5.4 below, the semantics of these root aorists were most likely fientive ('become $x^{\prime}$ ) rather than stative ('be $\mathrm{x}^{\prime}$ ). The network seems particularly robust for adjectives of COLOR. Table 2 below gives the network as it is attested for the roots $\sqrt{\text { prath }^{i}}$

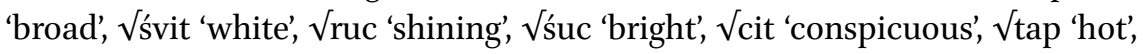

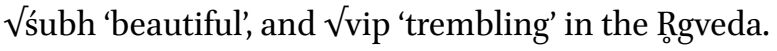

At its core (see Fig. 1), the network seems to consist of a root aorist corresponding to a Class I present. All of the root aorists have intransitive meanings, with either active or middle endings (the choice of which does not appear to be predictable). These root aorists can be renewed as either passive aorists or sigmatic aorists, regularly with intransitive meaning; at times, we also find thematic aorists, also intransitive. The present stems display more variety in terms of valency: Class I presents can be either intransitive or causative in meaning; in some, but not all, verbal systems, the opposition is signaled by middle vs. active endings. These Class I presents tend to be renewed as Class $\mathrm{x}$ presents, of both the intransitive and causative variety (with zero and lengthened grade of the root, respectively). Corresponding to the Class x causatives, we regularly 


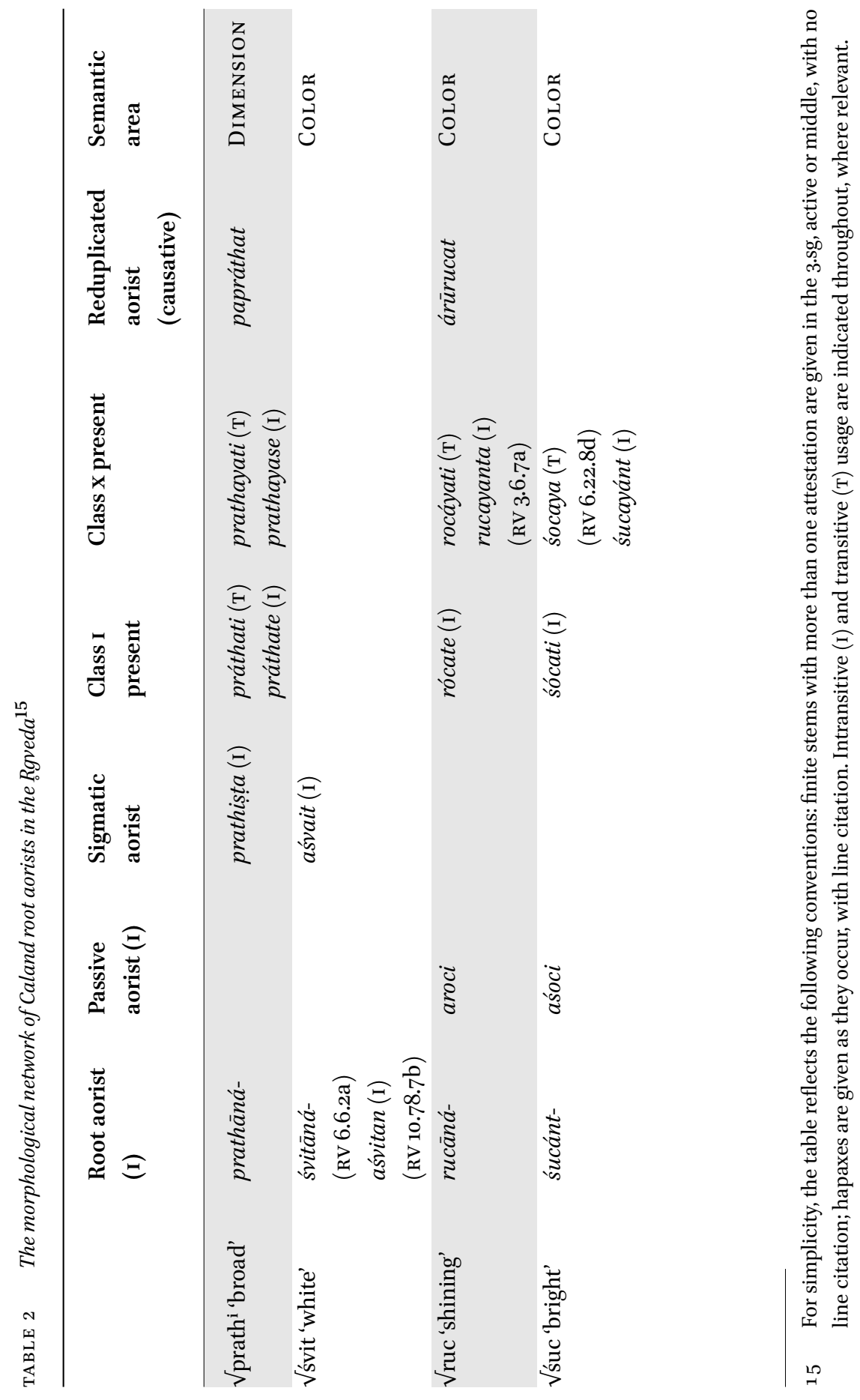




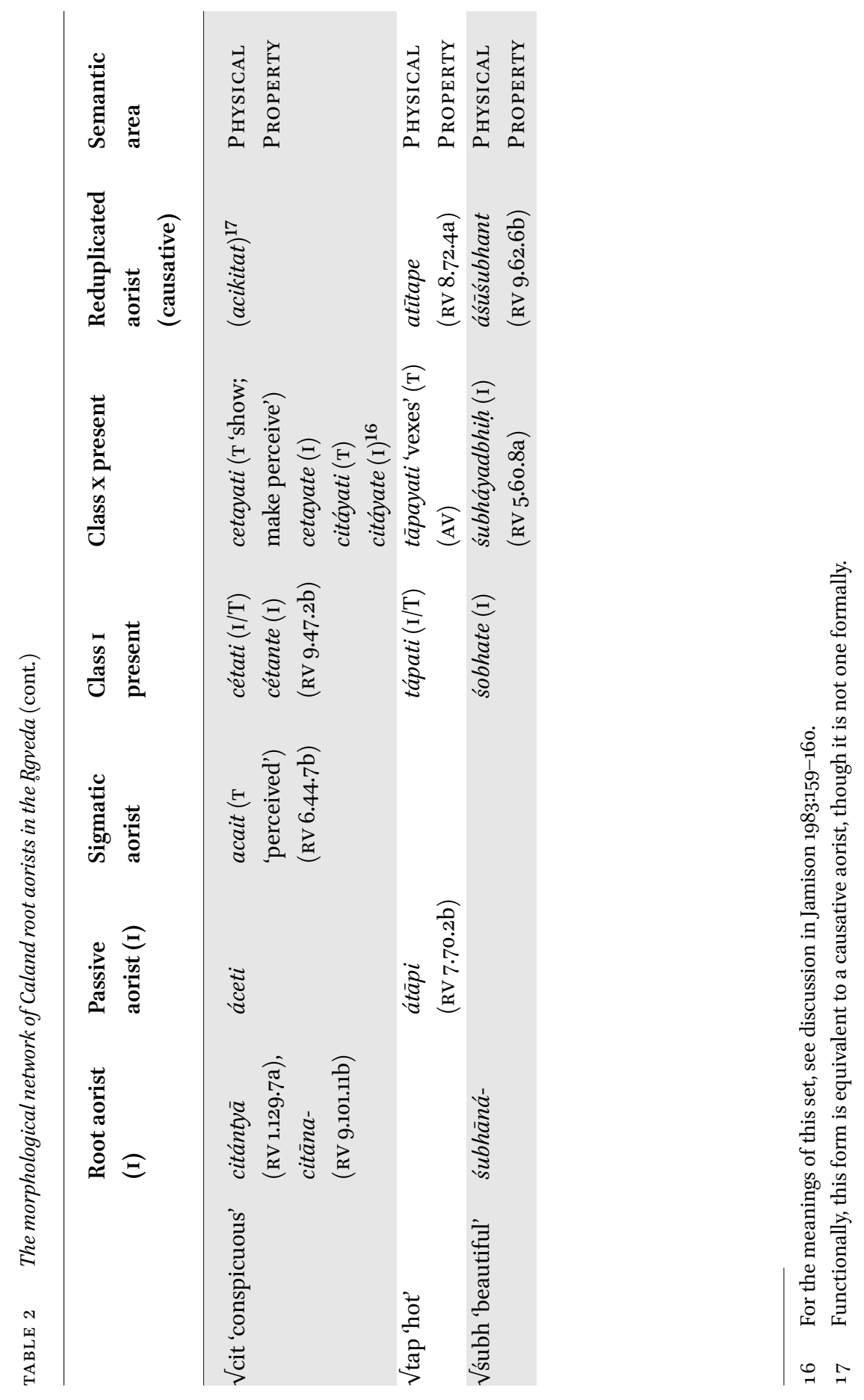




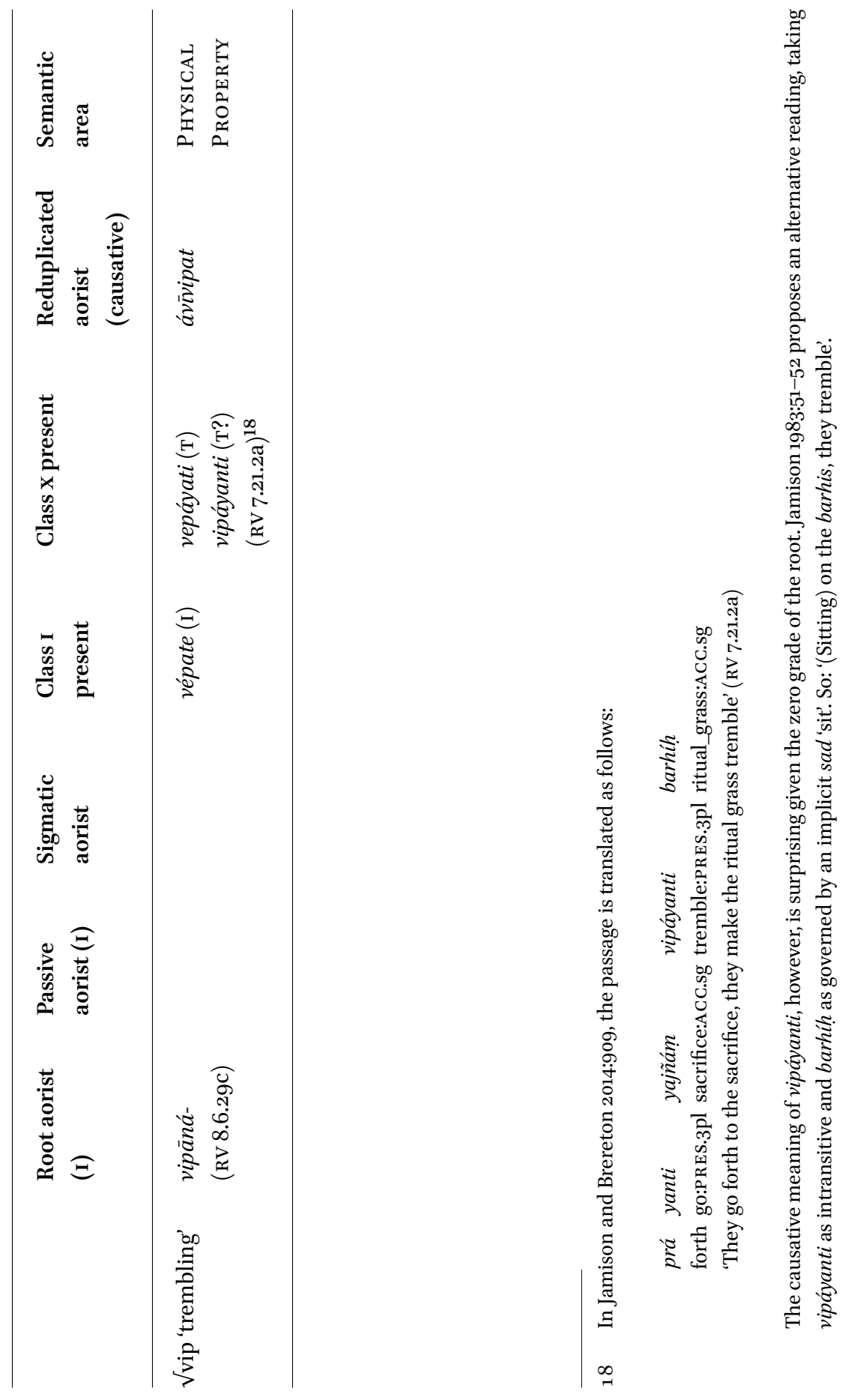




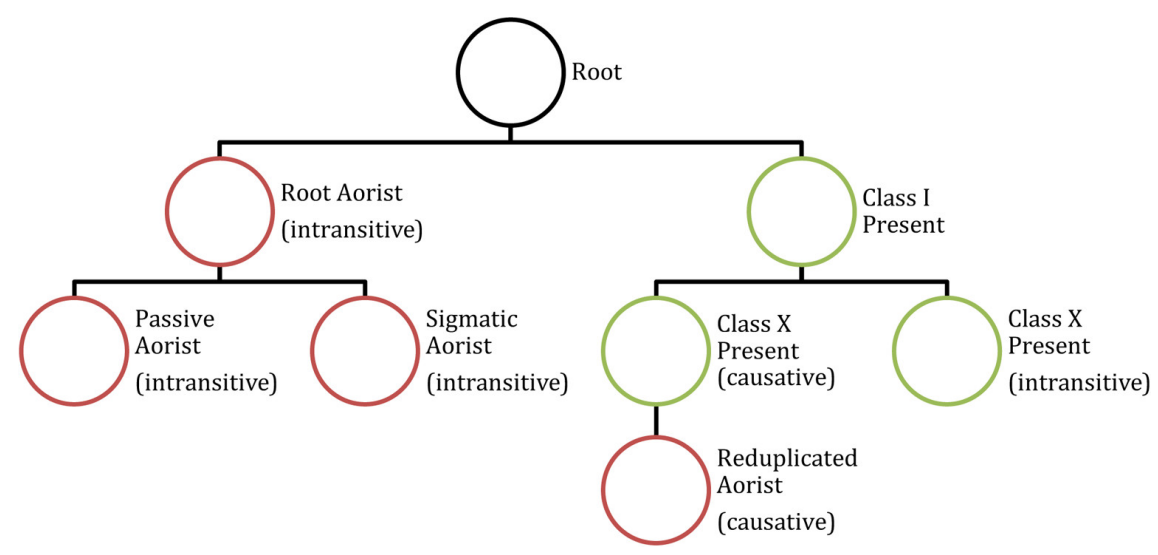

FIGURE 1 The morphological network of Caland root aorists in the Rgveda

find reduplicated aorists with causative meaning, which nicely complement the otherwise completely intransitive aorist system.

\subsubsection{Vruc 'Shining'}

Let us take $\sqrt{\text { ruc }}$ 'shining' as illustration. The existence of a root aorist is confirmed by the middle participle rucāná- 'shining/having become luminous.19 The intransitive root aorist was renewed as the passive aorist aroci 'has shone/ has become luminous'. In the present, this root derives a Class I thematic present rócate 'shines/is luminous', which has intransitive meaning; the root also has two Class x presents: rocáyati (causative), and the participle rucayanta (I) (RV 3.6.7a). ${ }^{20}$ Corresponding to the Class $\mathrm{X}$ causative present, we finally have a reduplicated aorist árürucat 'has caused to shine'. We can observe all of the members of the morphological network in the examples (17) to (22) below; note how, throughout the examples, the aorist participle rucāná- is used in attributive function, while the finite forms are used in predicative function (which in turn can be intransitive or causative).

19 A particular question concerns the semantics of the aorist participles to Caland roots in Vedic, and whether they should be translated as 'having become $\mathrm{x}^{\prime}$ (= 'being $\mathrm{x}$ ') or 'becoming x'. In other words, does rucāná- mean 'having become luminous', 'becoming luminous', or both? Dahl (2010:338-340) reports that aorist participles to atelic predicates can sometimes have the meaning 'having $x$-ed', and sometimes the meaning ' $x$-ing'. I find Dahl's examples for the latter meaning more compelling, but it is certainly advisable to judge the usages on a case-by-case basis.

$20 \quad$ For the origin of this latter type, see section 7 below. 
Before we look at the examples, I would like to make one important note about the translations: since English (like many modern IE languages) does not have verb-like adjectives, the translations that feel most natural to us will turn the adjectival predication into some sort of event. So, while the

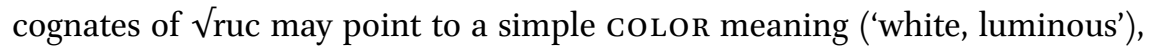
we tend to render the verbal forms as 'shine', instead of 'become white, become luminous' (fientive, aorist stem) or 'be white, be luminous' (stative, present stem), and the participial forms as 'shining', instead of 'having become/being white, luminous'. These translations, while felicitous in English, may at first disguise the original adjectival semantics of the root. This is not to say that the translations may not reflect the synchronic state in Vedic: it may very well be the case that the Caland roots that managed to hold on to their verbal paradigm the longest were also those which more easily could be understood as codifying events (e.g., 'shine') rather than properties (e.g., 'white'). In what follows, I have mostly retained the translations as they appear in Jamison and Brereton 2014; one should see that a more adjectival-sounding 'be/become white, bright, luminous' could be read for various 'shine, shine forth, blaze' etc.

\subsubsection{Predicative Usage (Intransitive)}

The first three examples show the predicative usage of three intransitive formations of the root: the passive aorist aroci 'has shone/has become luminous', the Class 1 present rócate 'shines/is luminous', and the Class x present rucayanta 'they shine/are luminous'.
(17) svàr
ná vástor
uṣásām
aroci

sun:NOM.sg like dawning:ABL/GEN.sg dawn:GEN.pl shine:PAOR.3sg.act 'like the sun at the dawning of the dawns, he has shone' (RV 7.10.2a)
(18) ví yát śúryo ná rócate brhád
PTC when sun:NOM.sg like shine:PREs.3sg.mid lofty:NOM.sg
bhấh
radiance:NOM.sg
'when (his) lofty radiance shines afar like the sun' (RV 7.8.4b)
(19) diváś
cid $\dot{a}$ te
rucayanta
rokáh

heaven.ABL.sg even to you.GEN.sg shine:PRES.3pl.act ray.NOM.pl 'your rays shine here even to heaven' ( $\mathrm{RV}$ 3.6.7a) 


\subsubsection{Predicative Usage (Causative)}

Equally common is the predicative usage of transitive (causative) formations to the root (compare with (18), where súryah 'sun' was Nom.sg and took the intransitive rócate 'shines/is luminous').
(20) tvám
súryam arocayah
you:NOM.sg sun:ACC.sg shine:IMPF.CAUS.2sg.act
'you (Indra) caused the sun to shine' (RV 8.98.2b)

Example (27) combines a predicative usage of the causative rocayat 'made shine' with an attributive usage of the aorist participle rucānáh 'shining/having become luminous':
(21) ayám
rocayad
arúco
this:NOM.sg shine:IMPF.CAUS.3sg.act unshining:ACC.pl rucānáh
shine:AOR.PTCP.NOM.sg
'this one here, himself shining, made the unshining ones shine' (RV 6.39.4a)

Finally, example (28) shows the causative aorist árürucat used predicatively:
(22) árūrucad ví divó rocaná
shine:CAUS.AOR.3sg.act PTC heaven:GEN.sg shining_realm:ACC.pl kavíh
poet:NOM.sg

'the poet has caused the shining realms of heaven to shine forth' (RV 9.85.9b)

\subsubsection{V'́uc 'Bright; Blazing'}

A similar network exists for V'uc 'bright'. Here, the root aorist is attested by the active participle śucánt- 'bright/having become bright'. Just like with $\sqrt{\text { ruc }}$ above, the intransitive aorist has been remade as the passive aorist aśoci has blazed/has been set ablaze'; we also have one instance of a thematic aorist aśucat (I) 'blazed/became bright'. The root forms a Class I present with active endings śócati (I) 'blaze/is bright' and intransitive meaning. Finally, we have a Class $\mathrm{x}$ intransitive present participle śucáyant-(I), almost always used attributively, and a Class X causative present imperative śocaya (T) (RV 6.22.8d); no matching reduplicated aorist with causative meaning is attested. Note how, in the predicative usage, the root seems to have shifted away from pure color con- 
notation (as in 23) and specialized for the description of fire, which justifies the translation 'blaze' or even 'burn'. Example (27) shows this semantic specialization most clearly.

\subsubsection{Attributive Usage}

Example (23) shows a simple attributive usage of the aorist participle śucántam 'gleaming, having become bright':

(23) sasám ná pakvám avidac

grain:ACC.sg like ripened:ACC.sg find:AOR.3sg.act

chucántam

bright:AOR.PTCP.ACC.sg

'he found him, gleaming like a ripened grain' ( $\mathrm{RV}$ 10.79.3c)

\subsubsection{Predicative Usage (Intransitive)}

Examples (24) to (26) show predicative usages of three intransitive formations of the root: the passive aorist aśoci 'has blazed/has been set ablaze', the thematic aorist aśucat 'blazed/bacame bright', and the Class I present śócanti 'they blaze/are bright'.

(24) á agnír ágra uṣásām aśoci

PTC Agni:NOM.sg head:LOC.sg dawn:Gen.pl bright:PAOR.3sg.act

'Here, at the head of the dawns, Agni has blazed/has been set ablaze' $(\mathrm{RV} 7.8 .1 \mathrm{~d})$

(25) samanagá aśucaj jātávedāh

meeting_going:NOM.sg bright:AOR.3sg.act Jātavedas:NOM.sg

'entering the melee, Jātavedas blazed' (RV 7.9.4b)

(26) brhác chócanty arcáyạ

aloft bright:PRES.3pl flame:NOM.pl

'flames blaze aloft' (RV 5.17.3 d)

\subsubsection{Predicative Usage (Causative)}

Examples (27) and (28) show that both the Class I present imperfect injunctive śocah and the Class $\mathrm{x}$ present imperative śocaya can have transitive (causative) meaning. 
(27) maínam agne ví daho mábhí NEG:3sg.ACC Agni:voC.sg PTC burn:IMPF.INJ.2sg.act NEG:PTC śocah

bright:IMPF.INJ.2sg.act

'Do not burn him through, Agni, don't scorch him' (RV 10.16.1a)

(28) brahmadviṣe śocaya kṣám

brahma_hater:DAT.sg bright:PRES.CAUS.IMP.2sg earth:ACC.sg apáś ca water:ACC.pl coNJ

'enflame the earth and the waters against the hater of the sacred formulation' (RV 6.22.8d)

Finally, (29) shows a substantivized usage of the Class X intransitive participle śucáyanta 'the blazing (flames?)':

(29) kathá te

agne

śucáyanta

āyór

How you:Gen.sg Agni:voc.sg bright:PRES.PTCP.Nom.pl Ayu:Gen.sg

'How, o Agni, do the blazing (flames?) of you, of Ayu ...' (RV 1.147.1a)

\subsubsection{V'śvit 'White'}

A similar network can be found for $\sqrt{\text { śvit }}$ 'white'. Here, the root aorist is attested by both the middle participle śvitāná- '(having become/becoming) white, bright' (RV 6.6.2a) and, quite nicely, by the finite 3pl.act form aśvitan (I) 'they have shone forth/they have become white' (RV 10.78.7b). The intransitive aorist has been remade as the sigmatic aorist aśvait (I) 'she has shone forth/she has become white', which is the only member of the paradigm to occur more than once (note also how the root aorist and the sigmatic aorist form a metrical paradigm in examples 31 and 32 below). We have no evidence for a Class I present (of either intransitive or transitive meaning) or for a Class $\mathrm{x}$ causative present.

\subsubsection{Attributive Usage}

(30) sá śvitānás tanyatú

3sg.NOM white:AOR.PTC.NOM.sg thunder:NOM.sg

rocanastháh

luminous_realm_abiding:NoM.sg

'he is like the brightening thunder abiding in the luminous realm' (RV 6.6.2a) 


\subsubsection{Predicative Usage (Intransitive)}

(31) śubhamyávo náñ̃ibhir vy àśvitan beauty_pursuing:NOM.pl ornament:INSTR.pl PTC white:AOR.3pl.act 'like those in pursuit of beauty they have shone forth with their ornaments' (RV 10.78.7b)

(32) síndhur ná kṣóda urviyá vy àśvait river:NOM.sg like surge.ACC.sg widely PTC white:AOR.3sg.act 'like a river (spreading) its surge, she has whitened forth widely' (RV 1.92.12b)

Similar morphological networks could be described and illustrated for the other roots in Table 2 above.

\subsection{The $\mathrm{h}_{2} \mathrm{e}$-Conjugation and Other Traces of Caland Aorists in $\mathrm{IE}$}

The roots $\sqrt{r u c}$ 'shining', $\sqrt{s} u c$ 'bright', and $\sqrt{ }$ cit 'conspicuous' are all cited by Jasanoff (2003:168-169) as prominent examples of stative-intransitive $\left(h_{2} e^{-}\right.$ conjugation) aorists, within stative-intransitive systems (see Jasanoff 2003:155). It may then be that, in Jasanoff's terms, Caland root verbs were a subclass of the $h_{2} e$-conjugation. While the investigation of the place of the Caland root verbs within the verbal system of the parent language is a topic for another paper, I shall, for now, reconstruct Caland aorists with $h_{2} e$-conjugation endings (3sg.act * $-e$, etc.); such a reconstruction should be regarded as tentative, and one could equally provide the examples below with mi-conjugation endings instead (e.g., not all Caland roots may have been conjugated in the same way in the parent language).

Traces of Caland root aorists may await us elsewhere in IE as well. In Greek, we find a few intransitive $-\bar{e}$ - aorists and thematic aorists linked to the Caland

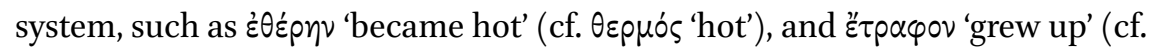
$\tau \alpha \rho \varphi$ ś 'thick, close' Hom+). Rau (2009:152, fn. 81) argues that these are both renewals of inherited root aorists (middle and active respectively). The Greek situation would then be similar to how Vedic remade Caland root aorists into passive aorists or sigmatic aorists. This also raises the question as to whether in Vedic too, some thematic aorists may continue older Caland root aorists (as aśucat above seems to do).

\subsection{Why Root Aorists? A Typological Parallel}

It may be surprising, from a semantic point of view, that Caland roots would form root aorists, and not root presents, as their base forms. After all, if we think 
of a property (e.g., 'being red') as a time-stable concept, similar to a state, we would expect it to yield an imperfective root in IE. The opposite configuration, however, is not uncommon. It is in fact parallel to the situation in Yimas, a Papuan language of New Guinea that has a class of verb-like adjectives (next to two more classes of adjectives, which I shall mention in section 7 below). In Yimas, verb-like adjectives "in their basic meaning are process verbs: they only assume the stative meaning by virtue of the Irrealis suffix $-k$, which stipulates that the event is unbounded in time" (Foley 1991:95). Compare the fientive meaning in (33), without the irrealis suffix $-k$, with the stative meaning in (34), with the irrealis suffix.

(33) na-tyknt-t

sg.suBJ-become_heavy-PFV

'she got fat' (data from Foley 1991:94-95)

(34) apak tyknt-k-nmay

sister heavy-IRR-sg

'a fat sister'/ 'sister is fat' (second translation mine)

We can then argue that Caland roots were fientive in meaning ('to become $\mathrm{x}^{\text {') }}$ in (Pre)-PIE, and formed root aorists. Non-fientive meanings to these roots ('to be $\mathrm{x}^{\prime}$ ) were formed by deriving present stems. In what follows, we shall look more closely at how these Caland root aorists formed their present stems in IE. This will force us to understand in more detail how adjectival predication worked at different stages of the protolanguage.

Present Stems of Caland Root Aorists and the ${ }^{*}-e h_{1}$ - Stative

Just like any other root forming a root aorist, Caland roots could form a number of characterized present stems. In the Vedic data above, we have seen that Class I presents are common. Rau (2009:136-16o) has shown that, in Greek and Indo-Iranian, Caland roots could derive present stems using standard imperfective suffixes: ${ }^{*}-s k e / o-$, nasal suffix, ${ }^{*}-y e / o-$, ${ }^{*}-e / o$ - etc. These suffixes formed fientives, factitives, and statives.

As Caland root aorists were gradually lost, the derived imperfective stems became the cardinal members of the verbal paradigm. Among these derived imperfective stems, Rau (2009:112 fn. 10) remarks that statives are the least well attested, because they were in direct competition with the simple adjective, and they were liable to develop into fientives. Overall, it seems that the system 
was moving towards using nominal forms for encoding stable properties (i.e., using adjectives rather than statives), and verbal forms for encoding changes in those properties (i.e., fientives, factitives etc.).

One way of forming stative presents to Caland root aorists, however, proved particularly successful in a number of IE languages. This is the so-called ${ }^{*}-e h_{1^{-}}$ stative, a PIE formation that has attracted a great deal of scrutiny in recent years, as scholars have recognized its ties to the Caland system. Statives in ${ }^{*}-e h_{I^{-}}$ form an established category in Italic, Balto-Slavic, and Anatolian (and possibly Germanic and Tocharian). ${ }^{21}$ Landmark studies of the category are Watkins 1971 and Jasanoff 1978, 2002-2003. We have already encountered some of these formations in connection with our Vedic evidence above, where we have seen that some Caland roots display intransitive Class x presents. Yakubovich (2013) has recently argued that such presents (which, unlike transitive Class x presents, show zero grade of the root) reflect Caland derivatives of the shape *eh $-y e / o-$. Note that already Jamison (1977:302) had pointed out the connection of a group of such intransitive -áya- presents with stative meaning to the Caland system.

The *-eh ${ }^{-}$- morpheme has long puzzled researchers. Formally, it has no parallels in the verb system, but it appears identical to an instrumental singular ending of a root noun. Jasanoff $(1978,2002-2003)$ proposed an account of how such a nominal ending may have been repurposed as a verbal suffix. He argues that the pivot is to be found in the predicative usage of the instrumental singular of root nouns. He finds an instance of such usage in the Ved. gúhā construction, in which a frozen instrumental form ( $g u$ úh 'with hiddenness'), can combine both with the verbs 'make', 'put', and with the copula to signify 'make hidden' or 'be hidden', in a way that closely resembles the Lat. factitive calêfaciō 'I make hot' and stative calēre 'be hot'. When combining with the copula, and if the copula could be dropped, gúhā could then come to be perceived as fulfilling a verb-like role in the clause. The more complex question, which I think can now be answered more precisely, is how could such a construction could come to be used as present stems of Caland root aorists specifically. This question shall interest us for the remainder of the paper. In order to find an answer, we will need to take a step back and consider how adjectival predication worked in PIE (and Pre-PIE) as a whole.

21 In some languages in which they were used, the ${ }^{*}-e h_{1}$ - statives seem to have percolated into the aorist system. This is the case of Gk. p'r $\gamma \sigma \alpha$ 'I trembled', the Gk. passive aorists, and possibly the B-Sl. infinitive of stative verbs. This matter shall not concern us here, and is treated extensively in Jasanoff 1978, 2002-2003. 
Saying that, at an early stage, PIE realized its core adjectival meanings as verbs (i.e. Caland root aorists) does not mean that all of the adjectival meanings were expressed by verbs. In fact, languages will usually have alternative strategies to express adjectival meanings, and there may be overlap between the different strategies. Yimas (Papuan, New Guinea), for instance, has three distinct strategies: real adjectives, adjectival verbs, and adjectival nouns (Foley 1991:93-101). ${ }^{22}$ Overlap in the expression of the same adjectival meaning is seen in English:

(35) Adjective: I am afraid of cats

(36) Verb: I fear cats

(37) Noun: I have a fear of cats

While English does this only marginally, in some languages the presence of alternative adjectival predication strategies is pervasive. We can introduce some terminology to deal with these phenomena (after Stassen 1997:155-206). Languages like Japanese, where some adjectives are verb-like and some are noun-like, are said to have a SPLIT ADJECTIVE system. Languages where the same property-concept (= adjectival) root can take nominal or verbal inflection are said to have a SwITCH AdJEctive system. In switch systems, the choice between nominal or verbal predication often depends on some additional parameters (e.g., permanence vs. impermanence or the like).

So far, I have argued that, at an early stage of PIE, core adjectival meanings (DIMENSION, AGE, VALUE, COLOR, PHYSICAL PROPERTY, and a few HUMAN PROPENSITY) were expressed verbally, by the Caland roots. But how were other adjectival meanings (DIFFICULTY, SIMILARITY, POSITION etc.), or less central adjectival meanings among the core semantic types expressed? In what follows, I survey two more strategies for adjectival predication in PIE: the instrumental predicative construction and the nominative predicative construction. I further argue that the instrumental predicative construction is the older of the two strategies.

22 In Yimas, these strategies express separate adjectival meanings (e.g., 'big' and 'good' are real adjectives, while 'heavy' and 'tall' are adjectival verbs). In the terminology introduced below, Yimas has a split adjective system. 


\subsection{The Instrumental Predicative Construction}

To express adjectival meanings not already covered by their adjective class, languages often use nouns expressing property concepts (these are usually abstract nouns), plus a construction that specifies that $\mathrm{x}$ has that given property. ${ }^{23}$ Something like:

(38) Predicative: the cat is with intelligence.

(39) Attributive: a cat with intelligence.

Several IE languages indeed have a similar construction, in which a NP in the instrumental case is used to attribute a property to a referent. MeierBrügger (2003:S 408) calls these "instrumentals of constitution"; ${ }^{24}$ see Delbrück 1893:240-242. Latin shows this construction most clearly: here the ablative (functionally, < PIE instrumental) is used for expressing impermanent properties; this is normally labeled "ablative of description" (for more examples, see Flocchini et al. 2001:292, 329).
(40) Britanni ...
capillo
sunt
promisso
Britanni:NOM.pl hair:ABL.sg be:PRES.3pl long:ABL.sg
'the Britanni wear their hair long' (Caes. B.G. 5.14.3)

A similar construction exists in Greek (at least if we take this as an instrumental and not a dative, see Meier-Brügger 2003:s 408):

$\begin{array}{ccc}\text { (41) } t i-r i-p o & e-m e & \text { po-de } \\ \text { tripos } & \text { hemēe } & \text { pode }\end{array}$

tripod:NOM.sg one:INSTR.sg foot:INSTR.sg

'a tripod with one leg' (PY Ta 641.1)

In Lithuanian:

(42) mergà ilgaĩs plaukaĩs

girl:NOM.sg long:INSTR.pl hair:INSTR.pl

'a girl with long hair' (Delbrück 1893:241)

23 This is particularly common for languages with a small, closed adjective class. see Schacter and Shopen 2007:15-16 for a collection of examples.

24 Coincidentally, this is precisely how Yimas construes its adjectival nouns, which occur with the postposition kantk- 'with', "often used to express possession or accompaniment"; adjectival meanings expressed in this way include 'cold', 'hot', 'sick', 'happy', 'dirty', 'tasty' (Foley 1991:98-99). 
And (if somewhat marginally and somewhat late) in Sanskrit (Speijer 1886:50):
(43) vividhyairțumaị kānanam
many_trees:INSTR.pl forest:ACC.sg
'a forest with manifold trees' (Rāmayana 3.7.3)

We can then posit a similar INSTRUMENTAL PREDICATIVE CONSTRUCTION for PIE, which could be used for adjectival meanings not expressed by Caland roots:

(44) Predicative: the cat is [with intelligence $]_{\mathrm{INSTR}}$

(45) Attributive: a cat [with intelligence/of intelligence $]_{\text {INSTR }}$

In positing this construction, we are not alone: Schindler (1980) too argued that the predicative usage of the instrumental could be reconstructed for PIE on the basis of a number of parallels in the daughter languages (the gúh $\bar{a}$ construction above, the Latin calēfaciō type in Jasanoff's analysis, and possibly the predicative instrumental in Balto-Slavic). Schindler himself argued that the predicative usage of the instrumental lay at the basis of the Indic cviconstruction (for which see now Balles 2006, 2009). ${ }^{25}$

\subsection{The Nominative Predicative Construction}

The instrumental predicative construction is of course different from the NOMINATIVE PREDICATIVE CONSTRUCTION, in which a noun is predicated of another noun, meaning identification rather than attribution of a property. In this construction, both nouns (the predicated one and the subject of the predication) show case agreement, normally in the nominative:

(46) $[\text { the cat }]_{\text {NOM }}$ is $[\text { a general }]_{\text {NOM }}$

25 Balles 2006 is an extensive treatment of the Old Indic cvi-construction; in investigating the origin of the construction, Balles surveys IE and typological material on adjectival predication, some of which I touch upon as well. The consequences for PIE reconstruction of her work are summarized in Balles 2009. In what follows, for convenience, I will primarily make reference to the 2009 paper, while giving reference to the 2006 book treatment for more detailed coverage. 
This is also the standard strategy used for adjectival predication with nounlike adjectives in most IE daughter languages; adjectives in this construction have to agree in gender and number, not only case, with the noun they modify.

I would argue that this construction would not have been available for adjectival predication with nouns in Pre-PIE, and that its usage for adjectival predication in the daughter languages is contingent on the development of nounlike adjectives (e.g., 'intelligent'), distinct from nouns that express adjectival meanings (e.g., 'intelligence'). On this last point, my account diverges crucially from that of Balles (2009:13), who believes that the instrumenta ${ }^{26}$ and the nominative strategies were respectively "marked" and "unmarked" options available to PIE speakers for realizing adjectival predication with nouns with adjectival meaning (what she labels "property concept nouns"), with the instrumental strategy specializing in "transitory semantics". ${ }^{27}$ Rather, I think that the two strategies (the nominative and the instrumental) reflect two separate chronological layers of adjectival predication in IE: the older layer (Pre-PIE) would have featured Caland Root verbs and instrumental predicative constructions with nouns. The newer layer (PIE) would feature nominative predicative construction with adjectives, a few remnants of Caland verbs (as seen above), and

26 In Balles' view, the instrumental strategy "is not really an instrumental in the sense of the concrete case, but rather an adverbial form (which historically of course may go back to an instrumental)" (Balles 2009:5). This interpretation is available for my account too, though I personally do not see it as a necessary step.

27 While this kind of alternation is well-documented for adjectives crosslinguistically (see Stassen 1997:189-193), I am not persuaded by Balles' argumentation that it held for the earliest stages of PIE, and that it held with the distribution that Balles has in mind. In Balles' reconstruction, the "adverbial" version of the property-concept noun (our instrumental predicative construction) would be used only for telic and ingressive predication, while the inflected version (what I would call the nominative strategy) would be used for attributive usage and stative predication. I believe that the fact that the instrumental predicative construction seems to lie at the basis of the IE ${ }^{*}$-eh $h_{1}$ - stative (see below) directly contradicts Balles' hypothesis: this would be a case of a stative predication clearly associated with the instrumental predicative construction. I also do not see a strong reason to attribute different semantics to the nominative and instrumental constructions respectively, since in my account they instantiate two different chronological layers, which came to coexist: the instrumental construction represents the older layer, the nominative construction the newer. With the nominative predicative construction, using different auxiliaries (e.g., 'be' vs. 'become') can give the difference between telic/ingressive predication and stative predication (this option is available in many modern IE languages, English included); in the early PIE switch system described below, the Caland root aorist would have done the telic/ingressive predication, while the instrumental predicative construction (then reanalyzed as the stative) would have done the stative predication. 
some more remnants of the instrumental predicative construction with nouns. For a glimpse of what may have happened during the transition between the two chronological layers, we may now turn to the origin of the * ${ }^{*} h_{1}$ - stative.

The discussion so far has pointed out a functional similarity between Caland verbs and the instrumental predicative construction (of which Jasanoff's gúhā construction is a particular case): they were both strategies for the encoding of adjectival meanings in (Pre)-PIE. The harder question to address is how did the instrumental predicative construction (which, in my account, was not original to Caland roots) come to be associated with the Caland system, and how did it come to function as the present stem to Caland root aorists.

To explain this distribution, we can picture PIE working with a switch adjective system. Such a system may in have come into being as PIE was restructuring its adjectival predication. Stassen (1997:158) in fact claims that a switch configuration "can be viewed as a manifestation of the last stage in a typological shift" from verb-like adjectives to noun-like adjectives. This is exemplified in the history of Arabic: "While Classical Arabic allowed verb-noun switching for a sizeable set of predicate adjectives, the verbal-encoding option for adjectives has been given up in the modern Arabic dialects" (ibidem).

In a switch system scenario, two strategies of predication, one verbal and one nominal, are possible for the same adjectival root. ${ }^{28}$ For many switch system languages, the choice between verbal and nominal predication is linked to Aktionsart: fientive meanings ('become $\mathrm{x}^{\prime}$ ) are expressed verbally, while stative meanings ('be $\mathrm{x}^{\prime}$ ) are expressed nominally. This configuration is well attested crosslinguistically, and is found in Afro-Asiatic languages such as Biblical Hebrew (Semitic), as well as in Oromo (Cushitic).

(47) gudd-at-e

big-INCH-3sg.PST

'He grew big' (Owens 1985:251)

28 Descriptively, this situation holds for Caland roots in many IE daughter languages, where members of the Caland system have both nominal and verbal exponents. In the daughter languages, however, both the nominal and the verbal strategy use forms that are morphologically derived, i.e., secondary (cf. Latin calidus vs. calēre). At an earlier stage, we can expect that both strategies would have used underived, primary forms. The development of the ${ }^{*}$-eh $h_{1}$ - stative offers us a glimpse precisely into such a stage. 
(48) Innii $\quad$ gúdd-aa
3sg.M.Nom big-ADJ.M
'He is old' (Owens 1985:32)

Contrast the fientive past reading of the verbally-inflected (47) with the present stative reading of the nominally inflected (48), where the root gudd- 'big' takes an overt adjectival ending $-a a$. Note also how, in the nominal strategy, the copula is absent.

In a PIE switch system, one could then effectively have the following opposition:

(49) Aorist: [the cat] ${ }^{* *} h_{1} r e{ }^{2} w d^{h}-e$ 'the cat became red'

(50) Present: [the cat] " $h_{1} r u d^{h}$-éh $h_{1}$ the cat is red' (lit. 'the cat is with redness')

Note that we are in effect assuming that ${ }^{*} h_{1} r e w d^{h_{-}}$, at this stage, could work as root aorist as well as a root noun. This feature could likely have come about as the system was transitioning, and nominal predication was gaining ground over verbal predication: at this stage, Caland roots started aligning themselves to the new system by forming root nouns as well. This step does not rest on mere speculation: we have evidence for a few Caland root nouns (Rau 2009:73), cf. Lat. lūx 'light', Ved. śrí- 'beauty, splendor', etc. In fact, Schindler (1980:392) believed that these root nouns were at the basis of the system (see also Nussbaum 1999:404). ${ }^{29}$

In the PIE switch system scenario above, the bare instrumental ${ }^{*} h_{1} r u d^{h}-e h_{1}$ is effectively functioning as the present of the aorist ${ }^{* *} h_{1} r e w d^{h}-e$. It is then not hard to assume that ${ }^{*}-e h_{1}$ - itself could be reanalyzed as a present stem formant,

29 The limited evidence for Caland root nouns presents us with two alternative scenarios to the one I have been discussing. (1) The root nouns could be older, and the root verbs newer. I would be unsure as how to motivate such a scenario, especially considering that overall IE seems to be moving away from verb-like adjectives, not towards them. (2) Caland roots could be neither verbal or nominal in nature, but simply become nouns or verbs according to the morphology that they receive: this would be in fact a switch system scenario. I believe that this scenario holds true for the phase of PIE that is accessible through direct reconstruction, and that is responsible for the creation of the ${ }^{*}-e h_{1}$ - stative (one could reconstruct this phase directly on the basis of the Vedic evidence in (53)-(55)). In my account, this phase is a stage in a larger typological shift between verb-like adjectives and noun-like adjectives, and in Pre-PIE (not accessible through direct reconstruction) Caland roots were exclusively verbal. While this account has some explanatory power, accepting a reconstruction at this depth may ultimately be a matter of taste. 
and provided with verbal inflection (possibly, as Jasanoff 2002-2003 suggests, through derivation with *-ye/o-). We would then have the following system:

(51) Aorist: [the cat] ${ }^{* *} h_{1}$ réw $d^{h}-e$ 'the cat became red'

(52) Present: [the cat] " $h_{1} r u d^{h}$-é $h_{1}-(y e-) t i$ 'the cat is red'

For the root $\sqrt{r u c}$ 'shining', we in fact have all of the pieces of the system attested within Vedic:

(53) Root aorist:

rucāná

(54) Root noun used in instrumental predicative construction: rucá

(55) ${ }^{*}-e h_{1}$ - present (per Yakubovich 2013): rucayanta ${ }^{30}$

We have several examples, in Vedic, of the instrumental rucá used predicatively (e.g., RV 5.561, RV 9.62.13c, 9.64.28a). The most striking is perhaps RV 3.15.6c, where we find the instrumental predicative construction (noun-like strategy) combined with the root aorist participle (verb-like strategy). This passage effectively exemplifies the switch system discussed above:

(56) devébhir deva surúcā rucānó god:DAT.pl god:vOC.sg good_flame:INSTR.sg shine:AOR.PTCP.NOM.sg 'O god with the gods, aflame with good flame' (RV 3.15.6c)

The reanalysis of ${ }^{*} h_{1} r u d^{h}$-éh $h_{1}$ into ${ }^{*} h_{1} r u d^{h}$-éh $h_{1}-t i$ was first proposed by Jasanoff (1978), but without factoring the root aorist in the picture. The addition of the root aorist makes the analogy much more compelling (note that in this scenario, one can still operate with ${ }^{*} h_{1} r u d^{h_{-}}-h_{1}-y e / o-$, after Jasanoff 2002-2003). In sum, I believe that Jasanoff's (1978) analysis of the origin of the *-eh ${ }^{\text {- stative }}$ is essentially correct, but a few details about its formulation can be improved upon, namely: (1) the gúhā construction in Vedic should be conceived as a parallel for the $\mathrm{PIE}^{*}$-eh $h_{1}$ - stative, rather than as its historical source: both constructions derive from the same source (PIE instrumental predicative construction), and both are liable to patterning and grammaticalizing in similar ways; but gúhā has not grammaticalized into a verbal stem in Vedic, while we must assume that other ${ }^{*}-e h_{1}$ - forms had already done so in PIE (Jasanoff too is aware

30 The short vowel in rucayanta ( $\mathrm{RV}$ 3.6.7a) can be accounted for by prosodic shortening of $\bar{a}$. This would have happened originally before -nt-, per Lubotsky 1989; see the discussion in Yakubovich 2013:10-12. The derivation is thus PIE *luk-éh $-y e / o->{ }^{*} r u c-\bar{a} y a->>$ Ved. rucáya-. 
of this paradox, see 2002-2003:146); (2) it was only the instrumental of Caland root nouns specifically (not that of root nouns in general) that grammaticalized into present stems already in PIE, because only Caland roots had root aorists that could spark the reanalysis. In fact, gúhä itself (which does not have a root aorist) does not obtain verbal inflection in Vedic or later Sanskrit (although it does develop into a stative in Baltic, attesting to its compatibility with stative predication).

\section{$9 \quad$ Conclusion}

The Caland system developed from a class of Pre-PIE adjectives which had a verb-like morphosyntactic profile (these may be described as a sub-class of intransitive verbs, like the Japanese $-i$ adjectives). In Pre-PIE, the system was presumably limited to finite forms of a root aorist used in predicative function, and root aorist participles used in attributive function. Next to this, Pre-PIE had an instrumental predicative construction that could be used with nouns expressing adjectival meanings.

When PIE shifted to having noun-like adjectives, probably as a result of developing into a mainly dependent-marking language (see below), the Caland roots had to be adapted to the new system via derivation. They then received suffixes which clearly shaped them into nouns, adjectives, and verbs; these are the Caland suffixes. The old root aorists (once the basis of the system) were gradually eliminated, and only a few direct and indirect traces of them remain in the daughter languages.

As the system was shifting, PIE came to have a switch adjective strategy, similar to that found in Biblical Hebrew and Oromo. In this strategy, Caland roots could form both root nouns and root verbs; in particular, adjectival predication was realized nominally in the present (using the instrumental of a new Caland root noun), and verbally in the aorist (using the old Caland root aorist). It is in this system that the instrumental ${ }^{*}-e h_{1}$ was reanalyzed as an imperfective suffix, and was provided with verbal inflectional endings, yielding the stative present of the Lat. calère type. In some daughter languages, common imperfective suffixes (plain thematic ${ }^{*}-o / e^{-},{ }^{*}-s k e / o^{-},{ }^{*}-y e / o-$, nasal affixes etc.) were employed to the same end.

The conclusions presented here were reached using a variety of tools, including comparative reconstruction, internal reconstruction, and linguistic typology. Of course, the reach of these tools is different, and so is their precision, with comparative reconstruction being the most fine-grained, and typology the least. Terminologically, I have tried to differentiate between what is recon- 
structable via the comparative method (PIE, marked with a single asterisk *), and what is reconstructable by a combination of internal reconstruction and typological considerations (Pre-PIE, marked with a double asterisk ${ }^{* *}$ ).

The respective roles of comparative reconstruction, internal reconstruction, and linguistic typology in the practice of historical linguistics are rightly debated, and while comparative and internal reconstruction are part of the standard toolkit of the Indo-Europeanist, typology is usually employed with greater caution. One could perhaps coin the maxim that, in IE linguistics, typology is seen as a good servant, but a bad master. ${ }^{31}$ Following some broad-brush applications of syntactic typology to the reconstruction of PIE syntax in the 1960 and 1970 (for a searing criticism of which see Watkins 1976), the practice of Indo-European linguistics has developed a healthy skepticism in this area, which survives to this day. It is now normally accepted that typology could work as a corrective to our reconstructions (and that we should endeavor to reconstruct a proto-language that is typologically plausible), but there is often resistance to revising reconstructions based on typological considerations alone. The most notable illustration in this regard is the extensive debate on the reconstruction of the PIE consonant inventory, which is still far from settled. ${ }^{32}$ Yet other areas hold more promise, especially when typology is combined with linguistic theory and careful philological assessment of the data. Typological objections have been raised from an early date with respect to the reconstruction of accent and ablaut paradigms (cf. Kiparsky \& Halle 1977, Kiparsky 2010), and have recently gained considerable traction in the analysis of accentuation in the IE daughter languages (cf. Lundquist 2015, Sandell 2015:Ch. 7, Yates 2015). Typological considerations within the framework of grammaticalization theory can likewise be employed to clarify the original functions of PIE verbal categories. ${ }^{33}$

Finally, I would argue that a great service that typology can offer to the field of IE linguistics is to help us see these languages with fresh eyes: older IE languages are so deeply embedded in their grammatical tradition that we can rarely see them anew. As a result, several "exotic" linguistic features are described in non-IE languages well before they are identified in the IE languages. Discourse configurationality and discontinuous constituency were theoretically investigated for Warlpiri (1983) and Mohawk (Baker 1996) long before

\footnotetext{
31 For recent discussions of the role of typology in Indo-European and historical linguistics, see Melchert fthc. and Luraghi fthc.

32 For a brief summary, see most recently Luraghi fthc.:5-8.

33 For an example, see Bozzone 2012 on the PIE subjunctive.
} 
they were for Ancient Greek. ${ }^{34}$ The same goes for serial verb constructions, which were described for languages of Africa and Papua New Guinea long before they were suspected to have existed in PIE. ${ }^{35}$ Similarly, relational preverbs were first described for Native American languages (Craig and Hale 1988), and only much more recently for Homeric Greek (Imbert 2010). In all of these cases, while the data in the various old IE languages was not hidden, typological comparison provided helpful context and analytical insight.

For the Caland system, the larger typological picture sketched here, hopefully, can help us to organize the data into a more readily graspable narrative. While this paper is not likely to be the last word on this topic, I hope that this contribution can help us see adjectival predication in PIE with fresh eyes.

\section{Appendix: Typological Considerations Supporting a Verb-Like Adjective Class in Pre-PIE}

\section{A.1 Adjective Typology and the Locus of Argument Marking in the Clause}

Dixon (2010:32-36) has formulated the hypothesis that adjective typology tends to correlate with certain general syntactic features of a language, specifically, the locus of argument marking in the clause. In Nichols' (1986) terms, we can distinguish between head-marking languages and dependent-marking languages (there are also ø-marking languages and double-marking languages). Under this terminology, the verb is the head of the clause, so head-marking means marking of the syntactic roles in the clause on the verb; conversely, dependent-marking means marking of the syntactic roles in the clause on the NPS which are arguments of the verb.

Chechen, a Nakh-Daghestanian language that marks the syntactic roles of its arguments on NPs (using cases), and marks no agreement on the verb, is an example of a dependent-marking language.

34 On discourse configurationality, see now Goldstein 2015. On discontinuity, see Devine and Stevens 2000, Agbayani and Golston 2010.

35 On serial-verb constructions in non-IE languages, see the collected essays in Aikhenvald and Dixon 2006. The reconstruction of a (quasi-)serial-verb construction for PIE has been most recently proposed in Yates 2014 . 
(57) oox-a cha-ca txou-ø qeelira

1pl-ERG straw-INSTR roof-ABs cover.PST

'we thatched the roof/we covered the roof with straw' (Nichols and Bickel 2013)

In contrast, K'iche', a Mayan language that has no case marking on NPs but cross-references all of its core arguments on the verb, is a head-marking language.

(58) iwir la Pedro $x$-ø-u-tij
yesterday DET Pedro PFV-3sg.ABS-3sg.ERG-eat one banana
'yesterday, Pedro ate a banana'36

Dixon's generalization is that dependent-marking languages tend to have noun-like adjectives, while head-marking languages tend to have verb-like adjectives. To put it simply, the adjectives go where the syntactic marking is. Dixon argues that the history of Japanese illustrates this principle, whereby in the oldest layer of the language we find verb-like adjectives and absent (or optional) dependent-marking, ${ }^{37}$ while in the newer layer of the language we find noun-like adjectives and case-marking particles ( $g a$ and $o$ ). Dixon's ideawhich he presents as "speculative but not implausible" (2010:35) —is that the shift in clause marking type caused the realignment of the adjective class.

A similar situation may hold for Pre-PIE, if we are willing to engage in deep reconstruction. IE languages are mostly dependent-marking, in that all core syntactic roles are marked on the NPs using cases, while the verb is only marked for subject agreement. The deep reconstruction of IE, however, has often suggested a phase in which the core arguments were entirely marked on the verb and case marking was not as fully developed (that is, a phase in which Pre-IE would have been mostly head-marking). ${ }^{38}$

In sum, the development from Pre-PIE to PIE may have entailed a change from a primarily head-marking strategy to a primarily dependent-marking

$36 \quad$ I would like to thank Fidel Sontay for sharing his language with me. This sentence was elicited in spring 2014.

For the development of case particles in Japanese, see Shibatani 1990:340 ff.

38 This is the line of thinking that points out the similarities between the - $m i$ endings and the personal pronouns, and that suggests that the thematic vowel may have been the marking for a direct object; for a recent summary, which takes these observations quite far, see Kortlandt 1983, 2008. Effectively, the Pre-PIE situation would then be similar to the K'iche' example in (58) above, where both the subject and the direct object are cross-referenced 
strategy, and the shift of the typology of adjectives from verb-like to nounlike may have been a part of this transition. In this scenario, Pre-PIE may have been head-marking with verb-like adjectives, while PIE was dependentmarking with noun-like adjectives. Caland roots, with their verbal affinities, would be a remnant of the Pre-PIE stage of verb-like adjectives.

\section{A.2 Adjective Typology, Tense, and Aspect}

Another typological argument comes from the work on intransitive predication by Stassen 1997. Stassen (1997:357) claims that tensed languages tend to have noun-like adjectives, while aspectual languages tend to have verb-like adjectives. Somewhat simplifying, the idea is that adjectives tend to avoid tense marking, so that if verbs are marked for tense, adjectives will not be verbs. Under this model, (Pre)-PIE, understood as being primarily an aspect-marking language, is predicted to have verb-like adjectives. Daughter languages that are primarily tense-marking, on the other hand, are predicted to have nounlike adjectives. In her account of the development of the Caland system in PIE, Balles (2009:8, 2006:269-272) uses Stassen's model to argue that nounlike adjectives in PIE as we reconstruct it must be a recent innovation, and that Pre-PIE must have expressed adjectival meanings using two distinct strategies: (a) verbs with adjectival semantics and (b) "property concept nouns" that expressed "the adjectival as well as the abstract meaning in one form and one lexical entry" (10).

Although Balles argues that the Caland system originates with strategy (b) (i.e., property concept nouns), when listing some verbal roots with adjectival semantics as examples of strategy (a) (i.e., verb-like adjectives), she gives some unequivocally Caland material (PIE ${ }^{*} h_{1}$ reud ${ }^{h}$ - 'red', ${ }^{*} p e h_{2} g$ - 'hard', *(s)teyg'sharp', *swad- 'sweet', *mad- 'wet'). Because these roots are verbal in nature, Balles believes that they are not originally part of the Caland system. In this paper, I have argued precisely the opposite, namely that the Caland roots were originally verb-like adjectives, and that their nominal behavior (Balles' strategy (b)) was a later innovation (see section 7 above).

on the verb-word by means of affixes/clitics (the thematic vowel would be the object morpheme, the personal endings would be the subject morpheme), and no case marking for core argument exists. 


\begin{tabular}{llll}
\multicolumn{2}{c}{ Abbreviations } & & \\
1 & 1st person & IRR & irrealis \\
2 & 2nd person & M & masculine \\
3 & 3rd person & NEG & negation \\
ABL & ablative & NOM & nominative \\
ACC & accusative & NPST & non-past \\
ADJ & adjective & PAOR & passive aorist \\
AOR & aorist & PFV & perfective \\
AV & Atharvaveda & pl & plural \\
CAUS & causative & PRES & present \\
CONJ & conjunction & PST & past \\
DAT & dative & PTC & particle \\
ERG & ergative & PTCP & participle \\
GEN & genitive & REL & relativizer \\
I & intransitive & RV & Rgveda \\
IMP & imperative & Sg & singular \\
IMPF & imperfect & SUBJ & subject (of intransitive \\
INCH & inchoative & & verbs) \\
INJ & injunctive & T & transitive \\
INSTR & instrumental & VOC & vocative \\
IPFV & imperfective & & \\
& & &
\end{tabular}

\section{References}

Agbayani, Brian and Chris Golston. 2010. Phonological Movement in Classical Greek. Language 86.1.1-67.

Aikhenvald, Alexandra Y. and R.M.W. Dixon. 2006. Serial Verb Constructions: A CrossLinguistic Typology. Cambridge: Cambridge UP.

Baker, Mark. 1996. The Polysynthesis Parameter. Oxford: Oxford UP.

Balles, Irene. 2006. Die altindische Cvi-Konstruktion. Form, Funktion, Ursprung. Bremen: Hempen.

Balles, Irene. 2009. The Old Indic cvi Construction, the Caland System, and the PIE adjective. In Rasmussen, Jens E. and Thomas Olander (eds.), Internal Reconstruction in Indo-European. Methods, Results, and Problems. Section papers from the XVI International Conference on Historical Linguistics (Copenhagen, August 2003), 1-15. Copenhagen: Museum Tusculanum Press.

Bozzone, Chiara. 2012. PIE Subjunctive: Function and Development. In H. Craig Melchert (ed.), The Indo-European Verb: Proceedings of the Conference of the Society 
for Indo-European Studies, Los Angeles 13-15 September 2010, 7-18. Wiesbaden: Reichert.

Caland, Willem. 1892. Beiträge zur Kenntnis des Avesta, no. 19. Zeitschrift für vergleichende Sprachforschung auf dem Gebiete der Indogermanischen Sprachen 31:266268.

Caland, Willem. 1893. Beiträge zur Kenntnis des Avesta, no. 26. Zeitschrift für vergleichende Sprachforschung auf dem Gebiete der Indogermanischen Sprachen 32:592.

Craig, Colette and Ken Hale. 1988. Relational Preverbs in Some Languages of the Americas: Typological and Historical Perspectives. Language 64.2. 312-344.

Crowell, Thomas Harris. 1979. A Grammar of Bororo. Ithaca: Cornell UP.

Dahl, Eystein. 2010. Time, Tense and Aspect in Early Vedic Grammar: Exploring Inflectional Semantics in the Rigveda. Leiden: Brill.

Delbrück, Bertold, 1893. Vergleichende Syntax der indogermanischen Sprachen. Strassburg: Karl J. Trübner.

Devine, Andrew M., and Laurence D. Stephens. 2000. Discontinuous Syntax: Hyperbaton in Greek. Oxford: Oxford UP.

Dixon, R.M.W. 1982. Where Have all the Adjectives Gone? And Other Esssays in Semantics and Syntax. Berlin: Mouton.

Dixon, R.M.W. 2010. Adjective Classes in Typological Perspective. In Dixon, R.M.W. and Alexandra Y. Aikhenvald (eds.) Adjective Classes, A Cross-Linguistic Typology, 1-49. Oxford: Oxford UP.

Flocchini, Nicola, Piera Guidotti Bacci, and Marco Moscio. 2001. Nuovo Comprendere e Tradurre: Grammatica Descrittiva e Contrastiva della Lingua Latina. Milano: Bompiani.

Foley, William A. 1991. The Yimas Language of New Guinea. Stanford: Stanford U P.

Fortson, Benjamin W. IV. 2010². Indo-European Language and Culture: An Introduction. Maldon, MA: Wiley-Blackwell.

Goldstein, David. 2015. Classical Greek Syntax: Wackernagel's Law in Herodotus. Leiden: Brill.

Hale, Ken. 1983. Warlpiri and the Grammar of Non-Configurational Languages. Natural Language \& Linguistic Theory 1.1.15-47.

Imbert, Caroline. 2010. Multiple Preverbation in Homeric Greek: A Typological Insight. CogniTextes 4 .

Jamison, Stephanie W. 1977. Function and form of the-áya-formations of the RigVeda and AtharvaVeda. Ph.D. Dissertation, Yale University.

Jamison, Stephanie W. 1983. Function and form of the-áya-formations of the Rig Veda and Atharva Veda. Göttingen: Vandenhoeck \& Ruprecht.

Jamison, Stephanie W. and Joel P. Brereton. 2014. The Rigveda: The Earliest Religious Poetry of India. Oxford: Oxford UP.

Jasanoff, Jay. 1978. Stative and Middle in Indo-European. Innsbruck: Innsbrucker Beiträge zur Sprachwissenschaft. 
Jasanoff, Jay. 2002-2003. "Stative" *-ē- revisited. Die Sprache 43:2.127-170. Jasanoff, Jay. 2003. Hittite and the Indo-European Verb. Oxford: Oxford UP.

Kaiser, Stefan, Yasuko Ichikawa, Noriko Kobayashi, and Hilofumi Yamamoto. 20132 Japanese: A Comprehensive Grammar. London: Routledge.

Kiparsky, Paul and Morris Halle. 1977. Towards a Reconstruction of the Indo-European Accent. In Larry Hyman (ed.), Studies in Stress and Accent, 209-238. Los Angeles: University of Southern California Press.

Kiparsky, Paul. 2010. Compositional vs. Paradigmatic Approaches to Accent and Ablaut. In Stephanie W. Jamison, H. Craig Melchert and Brent Vine (eds.), Proceedings of the 21st UCLA Indo-European Conference, 137-182. Bremen: Hempen.

Kortlandt, Frederik. 1983. Proto-Indo-European Verbal Syntax. Journal of Indo-European Studies 11:307-324.

Kortlandt, Frederik. 2008. Proto-Indo-European Verbal Syntax. (http://www.kortlandt .nl/publications/arto49e.pdf, accessed on 2015-05-20).

$\mathrm{LIV}^{2}=$ Lexikon der indogermanischen Verben. Die Wurzeln und ihre Primarstamme, Helmut Rix, Martin Kümmel, Thomas Zehnder, Reiner Lipp, Brigitte Schirmer (eds.). 2001. Wiesbaden: Reichert.

Lowe, John J. 2011. Caland Adjectives and Participles in Sanskrit and Proto-Indo-European. Paper presented at the 23rd Annual UCLA Indo-European Conference.

Lowe, John J. 2012. Caland Adjectives and Participles in the Rgveda: the case of -āna-, in Stephanie W. Jamison, H. Craig Melchert and Brent Vine (eds.), Proceedings of the 23rd Annual UCLA Indo-European Conference, 83-98. Bremen: Hempen.

Lowe, John J. forthcoming, Indo-European Caland Adjectives in *-nt- and Participles in Sanskrit, to appear in Historische Sprachforschung 126.

Lubotsky, Alexander. 1989. 'The Vedic -áya- formations' (Review of Jamison 1983). IndoIranian Journal 32:89-113.

Lundquist, Jesse. 2015. On the Accentuation of Vedic -ti-Abstracts. Indo-European Linguistics 3.1.42-72.

Luraghi, Silvia. Forthcoming. Typology and Historical Linguistics. In Alexandra Y. Aikhenvald and R.M.W. Dixon (eds.), The Cambridge Handbook of Linguistic Typology. Cambridge: Cambridge UP. (https://unipv.academia.edu/SilviaLuraghi, accessed on 2016-07-13)

Mayrhofer, Manfred. 1986-2001. Etymologisches Wörterbuch des Altindoarischen, 3 vols. Heidelberg: Carl Winter.

Meier-Brügger, Michael. 2003. Indo-European Linguistics. Berlin: De Gruyter.

Melchert, Craig H. Forthcoming. The Role of Indo-European Studies in the xxIst Century. In Paola Crisma \& Giuseppe Longobardi (eds.), Oxford Handbook of Diachronic and Historical Linguistics. (http://www.linguistics.ucla.edu/people/Melchert/Indo -European21stCentury.pdf, accessed on 2016-07-13)

Nichols, Johana and Balthasar Bickel. 2013. Locus of Marking in the Clause. In Dryer, 
Matthew S. and Martin Haspelmath (eds.), The World Atlas of Language Structures Online. Leipzig: Max Planck Institute for Evolutionary Anthropology. (http://wals .info/chapter/23, accessed on 2015-05-20)

Nichols, Johanna. 1986. Head-marking and dependent-marking grammar. Language 62:1.56-119.

Nussbaum, Alan J. 1976. 'Caland's Law' and the Caland System. Ph.D. Dissertation, Harvard University.

Nussbaum, Alan J. 1999. *locidus: An Account of Latin Adjectives in -idus. In Heiner Eichner and Heinz-Christian. Luschützky (eds.), Compositiones indogermanicae in memoriam Jochem Schindler, 377-419. Prague.

Owens, Jonathan. 1985. A Grammar of Harar Oromo (Northeastern Ethiopia). Hamburg: Buske.

Rau, Jeremy. 2009. Indo-European Nominal Morphology: The Decads and the Caland System. Innsbruck: Innsbrucker Beiträge zur Sprachwissenschaft.

Rau, Jeremy. 2014. The History of the Indo-European Primary Comparative. In Thomas Steer and Norbert Oettinger (eds.), Das Nomen im Indogermanischen: Morphologie, Substantiv versus Adjektiv, Kollektivum: Akten der Arbeitstagung der Indogermanischen Gesellschaft vom 14. bis 16. September 2011 in Erlangen, 327-341. Weisbaden: Reichert.

Sandell, Ryan. 2015. Productivity in Historical Linguistics: Computational Perspectives on Word Formation in Ancient Greek and Sanskrit. Ph.D. Dissertation, University of California, Los Angeles.

Schachter, Paul and Timothy Shopen. $2007^{2}$. Parts-of-speech systems. In Timothy Shopen (ed), Language Typology and Syntactic Description Volume I: Clause Structure, 1-6o. Cambridge: Cambridge up.

Schindler, Jochem. 1980. Die Herkunft der altindischen cvi-Bildungen. In Manfred Mayrhofer, Martin Peters, and O.E. Pfeiffer, (eds.) Lautgeschichte und Etymologie. Akten der VI. Fachtagung der indogermanischen Gesellschajl. Wien, 24.-29. September 1978, 386-393. Wiesbaden: Reichert.

Shibatani, Masayoshi. 1990. The Languages of Japan. Cambridge: Cambridge UP.

Speijer, J.S. 1886. Sanskrit Syntax. Motilal Banarsidass.

Stassen, Leon. 1997. Intransitive Predication. Oxford: Oxford UP.

Stassen, Leon. 2013. Predicative Adjectives. In Dryer, Matthew S. and Martin Haspelmath (eds.), The World Atlas of Language Structures Online. Leipzig: Max Planck Institute for Evolutionary Anthropology. (http://wals.info/chapter/118, accessed on 2015-05-02)

Tsujimura, Natsuko. 2014 ${ }^{3}$. An Introduction to Japanese Linguistics. Malden, MA: Wiley Blackwell.

Watkins, Calvert. 1971. Hittite and Indo-European Studies: The Denominatives in $-\bar{e}-$. Transactions of the Philological Society 70:51-93. 
Watkins, Calvert. 1976 [1994]. Towards Proto-Indo-European Syntax: Problems and Pseudo-problems. In Lisi Olivier (ed.), Selected Writings: Language and Linguistics, 242-263. Innsbruck: Meid.

Yakubovich, Ilya. 2013. Reflexes of Indo-European 'ē statives' in Old Indic. Transactions of the Philological Society 00:1-23.

Yates, Anthony. 2014. On the PIE "Quasi-Serial Verb” Construction: Origin and Development. In Stephanie W. Jamison, H. Craig Melchert, and Brent Vine (eds.), Proceedings of the 25th Annual UCLA Indo-European Conference, 237-255. Bremen: Hempen.

Yates, Anthony. 2015. Anatolian Default Accentuation and its Diachronic Consequences. Indo-European Linguistics 3.1.145-187. 